\title{
Key factors controlling massive graphite deposition in volcanic settings: an example of a Self-Organized Critical System
}

\author{
F.J. Luque ${ }^{\left(1,2,{ }^{*}\right)}$, L. Ortega ${ }^{(1)}$, J.F. Barrenechea ${ }^{(1,2)}$, J-M. Huizenga ${ }^{(3)}$, D. Millward ${ }^{(4)}$
}

(1) Dpto. Cristalografía y Mineralogía, Facultad de Geología, Universidad Complutense de Madrid, 28040 Madrid, Spain.

(2) Instituto de Geociencias, IGEO (UCM-CSIC).

(3) School of Environmental Sciences and Development, North-West University, Potchefstroom, South Africa.

(4) British Geological Survey, Murchison House, West Mains Road, Edinburgh EH9 3LA, UK.

* Corresponding author: jluque@geo.ucm.es

\section{Abstract}

Massive graphite deposition resulting in volumetrically large occurrences in volcanic environments is usually hindered by the low carbon contents of magmas and by the degassing processes occurring during and after magma emplacement. In spite of this, two graphite deposits are known worldwide associated with volcanic settings: Borrowdale, UK, and Huelma, Spain. As inferred from the Borrowdale deposit, graphite mineralization resulted from the complex interaction of several factors, so it can be considered as an example of self-organised critical systems. These factors, in turn, could be used as potential guides for exploration.

The key factors influencing graphite mineralization in volcanic settings are 1) an unusually high carbon content of the magmas, as a result of the assimilation of carbonaceous metasedimentary rocks, 2) the absence of significant degassing, related to the presence of sub-volcanic rocks or hypabyssal intrusions, acting as barriers to flow, 3) the exsolution of a carbon-bearing aqueous fluid phase, 4) the local structural heterogeneity (represented at Borrowdale by the deep-seated Burtness Comb Fault), 5) the structural control on the deposits, implying an overpressured, fluid-rich regime favouring a focused fluid flow, and 6) the temperature changes associated with fluid flow and hydration reactions, resulting in carbon supersaturation in the fluid, and leading to disequilibrium in the system. This disequilibrium is regarded as the driving force for massive graphite precipitation through irreversible mass transfer reactions. Therefore, the formation of volcanic- 
hosted graphite deposits can be explained in terms of a self-organized critical system.

Graphite mineralization in volcanic environments is related to precipitation from carbon-bearing aqueous fluids (Luque et al. 1998). Compared with other graphite occurrences formed through precipitation from fluids, volcanic-hosted graphite deposits are very uncommon. By contrast, after $\mathrm{H}_{2} \mathrm{O}, \mathrm{CO}_{2}$ is the second most common component of volcanic gases and fluids derived from magmas; other carbon species, like $\mathrm{CO}$ and $\mathrm{CH}_{4}$, are by far less abundant (Symonds et al. 1994). In particular, $\mathrm{CO}_{2}$ is a dominant volatile species in magmatic fluids and gases in subduction zones (Wallace 2005) and may originate in the mantle. In hightemperature volcanic gases there can be contributions from subducted marine limestone with slab carbonate and/or sedimentary $\mathrm{C}$, which in some cases may constitute the major fraction of the gases (Sano \& Marty 1995; Sano \& Williams 1996). The contribution of such subducted materials to the carbon budget of the mantle has been recognized by some authors (e.g. Zhu \& Ogasawara 2002) and is also recorded by the carbon isotopic signature $\left({ }^{13} \mathrm{C}\right)$ of diamonds (e.g. Deines et al. 2009; Stachel et al. 2009). Even as magmas rise through the crust, there are mechanisms that can add large amounts of $\mathrm{CO}_{2}$, such as the assimilation/melting of limestone or carbonaceous sediment (Lentz 1999; Ripley et al. 2002; Pedersen \& Larsen 2006). Lowenstern (2001) pointed out that $\mathrm{CO}_{2}$ behaves as a highly volatile species, both within magmas and in superjacent hydrothermal systems. In addition, except for carbonatite magmas, there are no major mineral phases that incorporate carbon within their structure and $\mathrm{CO}_{2}$ solubility is generally low in the melt. In hydrothermal systems, $\mathrm{CO}_{2}$ is not highly soluble under most conditions and precipitates as carbonate minerals at low temperatures. Usually, $\mathrm{CO}_{2}$ therefore exsolves from magmas and hydrothermal fluids, escaping to the surface. Although significant amounts of graphite (up to $8.8 \mathrm{wt} \%$ ) have been reported in some volcanic rocks from Greenland (Pedersen \& Larsen 2006), most magmas readily release their carbon along with the volcanic gases and this should account for the lack of graphite deposits in volcanic rocks.

In spite of the above arguments, there are two examples of large graphite deposits in volcanic settings at Borrowdale (Cumbria, UK) and Huelma (southern Spain) (Strens, 1965; Barrenechea et al. 1997, 2009; Luque et al. 1998, 2009a, b; 
Ortega et al. 2009, 2010). The aim of this paper is to discuss the key factors, as inferred from recent detailed studies on the Borrowdale deposit, which made possible the concentration of a huge amount of graphite in an a priori unfavorable geological setting. Such a discussion follows from consideration of the Borrowdale graphite deposit as an example of a self-organized critical (SOC) system. This concept was firstly proposed by Prigogine (1961) and Prigogine \& Nicolis (1977). Complex systems consist of a group of individual units existing far from equilibrium, interacting among themselves and from this interaction new properties arise. That is, Complexity Science studies the way non-equilibrium energy-flow systems spontaneously organize themselves, resulting in complex patterns which are not predictable from the individual components of the system. Bak et al. (1987) and Bak (1996) developed the idea of self-organized criticality applied to different natural systems further. Based on these works, Hronsky (2009) suggested that the formation of ore deposits can be also explained in terms of SOC systems.

As a SOC system, the formation of the Borrowdale volcanic-hosted graphite deposit comprises many interacting components and the dynamics of the system are dependent on their conjunction and complex interaction. The application of Complexity Science concepts to this deposit has very important implications not included within the current dominant paradigm used to explain mineral systems (i.e. source-transport-trap; e.g. Misra 2000), in which Borrowdale would be categorized as an "atypical deposit". By contrast, the SOC concepts allow understanding of this mineral system from a fluid-centered perspective as a self-organized fluid-flux system.

\section{Geological setting and petrography of the Borrowdale deposit}

The graphite deposit is hosted by andesite rocks belonging to the upper Ordovician (Katian) Borrowdale Volcanic Group (BVG), and by a probably contemporaneous hypabyssal dioritic intrusion (Fig. 1). This intrusion is in the immediate hanging wall of the Burtness Comb Fault which is inferred to lie above a repeatedly re-activated, deep-seated basement structure. The Burtness Comb Fault was therefore one of the fundamental faults that controlled the accumulation and preservation of the BVG (Millward 2002). Within the BVG, volcanism was mainly subaerial and corresponded to medium- to high-K calc-alkaline rocks related to subduction along a continental margin (Fitton et al. 1982; Beddoe-Stephens et al. 
1995). The BVG is underlain by anchizonal to epizonal metapelites and sandstones of the upper Cambrian to middle Ordovician Skiddaw Group. There is petrological and geochemical evidence for assimilation of Skiddaw Group lithologies by the BVG magmas (Fitton 1972; McConnell et al. 2002; Ortega et al. 2010).

The graphite deposit occupies approximately a $400 \mathrm{~m}$ length of a conjugate set of normal faults. The richest mineralized bodies are developed at the intersections of the faults as steeply inclined pipe-like bodies up to $1 \times 3 \mathrm{~m}$ in crosssection and from a few metres to over $100 \mathrm{~m}$ in length (Fig. 2a). The mineralized breccia pipe bodies suggest a quick upwards transport of overpressured (supralithostatic) fluids, similar to diatreme-like bodies. Graphite in the pipe-like bodies mainly occurs within the andesite and diorite wall rocks as subspherical to ellipsoidal aggregates (nodules up to $10-15 \mathrm{~cm}$ in diameter or major length), along with radiating aggregates of elongate epidote crystals [with average composition $\mathrm{Ca}_{2}$ $\left.\left(\mathrm{Mn}_{0.01} \mathrm{Mg}_{0.01} \mathrm{Fe}^{3+}{ }_{0.75} \mathrm{Ti}_{0.01} \mathrm{Al}_{2.25}\right)\left(\mathrm{Al}_{0.02} \mathrm{Si}_{2.98}\right) \mathrm{O}_{12}(\mathrm{OH})\right]$, chlorite, polycrystalline quartz, and minor pyrite and chalcopyrite. The wall rocks show an intense hydrothermal alteration to an assemblage containing quartz, chlorite, and albite, along with some disseminated small aggregates of graphite and late calcite veinlets. These features are indicative of an intense propylitic alteration, and provide evidence that the main stage of graphite precipitation occurred during this hydrothermal event (Luque et al. 2009a; Ortega et al. 2009, 2010). In addition to the pipe-like bodies, graphite also occurs associated with chlorite along fault planes (Fig. 2b) and as disseminations replacing the andesite and diorite (Fig. 2c). Graphite-chlorite veins represent a late event of graphite mineralization with respect to that of the pipe-like bodies (Ortega et al. 2010).

The Borrowdale deposit shows the greatest variety of crystalline graphite morphologies recognized to date from a single deposit, including flakes (which are the dominant morphology), cryptocrystalline graphite which may display colloform texture around quartz or wall-rock fragments, spherulites both within quartz and within flaky graphite, discs, and rings. The textural sequence of these graphite morphologies indicates that they crystallized from a carbon-bearing aqueous fluid (comprising $\mathrm{H}_{2} \mathrm{O}, \mathrm{CO}_{2}$, and $\mathrm{CH}_{4}$ as dominant fluid species) with progressively decreasing carbon supersaturation (Barrenechea et al. 2009). X-ray diffraction (XRD) and Raman data reveal that the graphite is highly crystalline as evidenced by the sharp and symmetrical peaks in the XRD patterns (Luque et al. 2009a) as well as by the very low intensity and area ratios of the disorder $\left(\sim 1350 \mathrm{~cm}^{-1}\right)$ to the order $(\sim 1580$ 
$\mathrm{cm}^{-1}$ ) peak in the first-order Raman spectra (Barrenechea et al. 2009). In the same way, the curves of differential thermal analysis of graphite from the Borrowdale deposit are also in agreement with its high crystallinity, showing strong exothermic peaks at temperatures in excess of $740{ }^{\circ} \mathrm{C}$ (Ortega et al. 2010). Stable carbon isotope signatures of individual graphite morphologies and bulk concentrates from the Borrowdale deposit are highly negative $\left(\delta^{13} \mathrm{C}\right.$ from -34.5 to $-24.3 \%$ ). In particular, within the pipe-like bodies, the quite homogeneous carbon isotopic signature both at the microscale and at the scale of each single graphite nodule suggests deposition between $500^{\circ}$ and $400^{\circ} \mathrm{C}$ at about $2 \mathrm{kbar}$ (Ortega et al. 2010). The highly negative $\delta^{13} \mathrm{C}$ values suggest that the carbon was derived from a biogenic source. As mentioned before, there is geological and geochemical evidence of assimilation of metapelite and sandstone from the Skiddaw Group by the volcanic host rocks. Therefore, these metasedimentary rocks must be regarded as the most probable source of carbon in the deposit (Barrenechea et al. 2009; Ortega et al. 2010).

The fluid inclusion study carried out on quartz fragments associated with the graphite nodules in the mineralized pipes have allowed the characteristics of the mineralizing fluids to be established. The studied fluid inclusions are both primary and secondary and record the fluids that were circulating during the hydrothermal event responsible for the coeval propylitic alteration and graphite mineralization (Ortega et al. 2010). The fluid inclusions can be grouped into low-density vapour-rich inclusions (V), and more dense liquid-rich inclusions (L). Petrographic, microthermometric and Raman data have allowed the definition of four types of inclusions (V, VS, L1 and L2; Table 1) revealing an overall fluid evolution characterized by: 1) progressive decrease in the $\mathrm{XCO}_{2} /\left(\mathrm{XCO}_{2}+\mathrm{XCH}_{4}\right)$ mole ratio $\left(\# X \mathrm{XO}_{2}\right.$ hereafter), and 2) progressive increase in the $\mathrm{XH}_{2} \mathrm{O}$. Considering the composition of the earliest $\mathrm{V}$ fluid and the pressure inferred from geological data and isochores of V-type inclusions (2 kbar; Ortega et al. 2010), graphite precipitation started from $\mathrm{CO}_{2}$-rich fluids during cooling from $\sim 500{ }^{\circ} \mathrm{C}$ to $\sim 400{ }^{\circ} \mathrm{C}$. The lack of isotopic zoning in graphite and the constant epidote composition indicate that $\mathrm{fO}_{2}$ of the fluid-rock system remained constant near the Fayalite-Magnetite-Quartz (FMQ) buffer during the mineralisation process (Luque et al., 2009a; Ortega et al., 2010). The dominant net graphite precipitation reaction in the initial stage of mineralization was $\mathrm{CO}_{2}+\mathrm{CH}_{4} \rightarrow 2 \mathrm{C}+2 \mathrm{H}_{2} \mathrm{O}$, and driven by hydration of the wall rock as shown by the presence of small graphite spherulites intergrown with chlorite in the andesite wall rock (Barrenechea et al. 2009). If this reaction had operated throughout the 
whole mineralizing process, V-type inclusions with higher $\# \mathrm{XCO}_{2}$ than actually found should have been generated (Ortega et al. 2010). In addition, the composition of the graphite-bearing VS inclusions, which contains only $\mathrm{CH}_{4}$, with no $\mathrm{CO}_{2}$, supports the involvement of a $\mathrm{CO}_{2}$-consuming reaction during the main stage of graphite deposition. The textural relationship between epidote and flaky graphite within the pipes strongly suggests that the main graphite precipitation event was dominated by the net reaction $\mathrm{CO}_{2} \rightarrow \mathrm{C}+\mathrm{O}_{2}$, which took place after hydration of the wall-rock ceased. This reaction is supported by the lack of stability of epidote for $\mathrm{XCO}_{2}>0.2$ (Ferry \& Burt 1982; Liou 1993) and type $\mathrm{V}$ fluid containing an average bulk $\mathrm{XCO}_{2}$ of 0.24 . Thus, epidote crystallization was likely triggered by the consumption of $\mathrm{CO}_{2}$ in the reaction of graphite precipitation. Considering the upper stability limit of the propylitic assemblage, the main event of graphite precipitation should have occurred at temperatures close to $400{ }^{\circ} \mathrm{C}$ (Ortega et al. 2010). The reduction of $\mathrm{CO}_{2}$ proceeded until the fluid was so much depleted in $\mathrm{CO}_{2}$ (and thus relatively enriched in $\mathrm{CH}_{4}$ ) that the net reaction $\mathrm{CH}_{4}+\mathrm{O}_{2} \rightarrow \mathrm{C}+2 \mathrm{H}_{2} \mathrm{O}$ became the dominant one (Ortega et al., 2010). This reaction prevailed during graphite deposition in the late chlorite-graphite veins as supported by the $\delta^{13} \mathrm{C}$ values (Barrenechea et al. 2009). Further details on the characteristics of the fluid inclusions and on the mechanisms of graphite precipitation at the Borrowdale deposit can be found in Luque et al. (2009a) and Ortega et al. (2009, 2010).

\section{The Borrowdale deposit as a self-organized critical (SOC) system}

According to Hronsky (2009) most ore-forming systems can be considered as examples of complex, SOC systems. To understand these systems, the combination and interaction of the components and their feedbacks within the system must be considered, rather than the individual components by themselves. In addition, SOC systems require a separation of timescales between energy input and output. This seems to be critical to the capacity of the system to self-organize. Otherwise, the behaviour of the system is completely dominated by the external applied force and no interesting behaviour emerges. The keys to ore formation are the dynamic processes that concentrate their mass flux.

As previously mentioned, volcanic environments are unlikely for the location of graphite deposits, because carbon species are released as magmas rise up. Thus, several conditions must occur together to provide a suitable scenario for massive 
graphite deposition in such environments. The graphite deposit at Borrowdale shows all these conditions and is a good example to understand the dynamic variables involved in the development of an ore deposit from the perspective of a SOC system.

The key factors which controlled the formation of the Borrowdale graphite deposit were 1) the unusually high carbon content of the magma, 2) the presence of the diorite intrusion, 3 ) the exsolution of a carbon-bearing aqueous fluid phase, 4) the local structural heterogeneity represented by the Burtness Comb Fault, 5) the focused fluid-flow regime, and 6) the temperature changes associated with fluid flow and hydration reactions that resulted in carbon supersaturation in the fluid. The combination of these factors concurred for the formation of this singular deposit as shown in Fig. 3.

Carbon content in magmas is usually low. About $1.5 \% \mathrm{CO}_{2}$ is soluble in silicate melts at $1400^{\circ} \mathrm{C}$ and $20 \mathrm{kbar}$ (Mattey 1991), although higher $\mathrm{CO}_{2}$ solubilities have been reported in mantle magmas (Wyllie \& Huang 1976; Eggler et al. 1976). It also has been shown that $\mathrm{CO}_{2}$ solubility increases with increasing pressure, oxygen fugacity and magma alkalinity (Pawley et al. 1992; Jendrzejewski et al. 1997; Lowenstern 2001). However, magmas generally degas quite strongly when their ascent slows down or stops at constrictions in conduits and, eventually, in magma chambers (Sarda \& Guillot, 2005). Giggenbach (1996) pointed out that the volatile contents of andesitic magmas related to subduction zones (like the BVG) are likely to be high enough to allow a separate, volatile-rich phase to be present during all stages of magma generation and migration. However, most of the andesite rocks lack graphite even as an accessory phase. Evidence suggests therefore that such carbon contents and conditions of degassing do not favour the formation of significant amounts of graphite in volcanic rocks. Furthermore, if degassing does not operate, carbon behaves as an incompatible element and it therefore concentrates in the residual fluids during magma crystallization.

A critical factor, therefore, in originating both the volumetrically large volcanichosted graphite occurrences at Borrowdale and Huelma, southern Spain (Barrenechea et al. 1997; Luque et al. 2009b) is the assimilation of carbonaceous pelitic material during evolution of the magmas (Fig. 3). Similarly, magmatic contamination by pelitic material has been invoked to explain the significant graphite content of andesites in western Greenland (Pedersen and Larsen, 2006) and dacites in the Erland Complex of the Faroe-Shetland Basin (Kanaris-Sotiriou 1997). At Borrowdale, geochemical, mineralogical, and isotope data implicate 
metasedimentary rocks of the underlying Skiddaw Group in the BVG magmas (Fitton 1972; Fitton et al. 1982; Beddoe-Stephens et al. 1995; McConnell et al. 2002). The stable carbon isotope ratios of graphite in the Borrowdale deposit, with light $\delta^{13} \mathrm{C}$ values ranging from -34.5 to $-24.3 \%$, clearly point to the biogenic origin of the carbon (Weis et al. 1981; Barrenechea et al. 2009; Ortega et al. 2009, 2010) and support this contention. The carbon content of the mudstones and siltstones of the Skiddaw Group ranges from 0.4 to 1 wt\% (Bebout et al. 1999; Ortega et al. 2010).

In this way, the magmas incorporated substantial amounts of carbon through the assimilation of these rocks. It is difficult to estimate how much carbon the magmas assimilated, since the exploitation of the graphite deposit goes back to the $16^{\text {th }}$ century. Tyler (1995) provided some figures for the tonnage of graphite production at the Seathwaite mine along its history (from 1597 to 1876). Considering all grades he quoted, a total amount close to 1023 tonnes of graphite results. Much of the grades (e.g. inferior, rock rubbish) probably do not correspond to pure graphite. So, we must accept that by using the raw figures we are overestimating the recorded $C$ percentage mined. If we assume an average density of $2.77 \mathrm{~g} / \mathrm{cm}^{3}$ (Lee 1986) and an average carbon content of $0.5 \mathrm{wt} \%$ for the Skiddaw metapelites, then the volume of assimilated metapelites would be close to $75,000 \mathrm{~m}^{3}$. Such estimation involves the assumption that all the assimilated carbon from the Skiddaw Group lithologies was later transferred as graphite to the deposit. Despite the uncertainty in these figures, they appear small in the context of models for the magmatic evolution of the BVG by AFC processes, as envisaged by Beddoe-Stephens et al. (1995) and McConnell et al. (2002). Thus, McConnell et al. (2002) suggested fractional crystallization/assimilation ratios of 0.4 to 1.5 . Unpublished $\delta \mathrm{O}^{18}$ values from some of the more contaminated BVG lavas require incorporation of up to about $40 \%$ bulk Skiddaw Group whilst some of the least contaminated rocks require $7-13 \%$ (MF Thirlwall, pers. comm.). These data would mean that a large proportion of the assimilated carbon was probably outgassed during the subaerial volcanism of the rocks of the BVG. In any case, the assimilation of carbon from the metasediments of the Skiddaw Group by the magmas of the BVG, constituted the first key factor for the massive graphite mineralization at Borrowdale to be formed.

The assimilation of such a huge amount of carbon poses an interesting question about the genesis of large graphite occurrences in igneous rocks considering the low solubility of carbon in silicate melts (only up to $12 \mathrm{wt} \%$ of $\mathrm{CO}_{2}$ can be dissolved in melts at pressure $>4.5 \mathrm{GPa}$ and at temperature between 950- 
$1000{ }^{\circ} \mathrm{C}$; Hermann \& Green 2002). In addition to experimental data, it has been shown that even in ultra-high pressure metamorphic rocks carbon can be hardly dissolved in silicate melts, but the reaction of silicate melt with carbonates could liberate some carbon (Korsakov et al. 2004, 2010; Korsakov \& Hermann 2006). Although there is no evidence of carbonate assimilation at Borrowdale and, taking into account that assimilation of carbonaceous metasediment occurred at much shallower levels as inferred from the conditions of crystallization of garnet in the andesitic rocks ( $P<5-7$ kbar; Fitton et al. 1982; Beddoe-Stephens \& Mason 1991), it is unlikely that carbon was present only as a dissolved species in the melt. Therefore, a fluid phase could have coexisted with the melt, but was never dissolved in it (i.e., the fluid phase was immiscible). Evidence at Borrowdale points to graphite precipitation from a carbon-bearing aqueous fluid containing $\mathrm{CO}_{2}$ and $\mathrm{CH}_{4}$, rather than from pure $\mathrm{CO}_{2}$. The solubility of such a fluid in the melt is unknown and additional studies would be needed to address this in detail. However, whether carbon coexisted as an immiscible phase with the melt, or was dissolved (or both) does not diminish the importance of metasediment assimilation as a key factor involved in massive graphite precipitation in volcanic environments discussed in this paper.

In the context of the SOC model, an essential element of ore-forming systems is a localized threshold barrier to flow (Hronsky 2009). At Borrowdale this barrier is represented by the dioritic intrusion. The key role of the hypabyssal dioritic intrusion in the emplacement of the Borrowdale graphite deposit was firstly recognized by Strens (1965). As previously mentioned, the BVG represents subaerial, subductionrelated andesitic volcanism and associated high-level intrusions. In the volcanic environment, the carbonic species derived from the assimilation would be released during magma ascent, and transferred to the surface, probably through the fault network (Giammanco et al. 1998). By contrast with the high-level volcanic setting, the crystallization of a batch of magma under subvolcanic-hypabyssal conditions at Seathwaite (i.e. the dioritic intrusion) provided a completely different scenario (Fig. 3). Such a scenario can also be recognized at Huelma where graphite mineralization is restricted to a sill within a submarine volcanic sequence (Barrenechea et al. 1997; Luque et al. 2009b). In the case of the Borrowdale deposit, the volatiles exsolved from the magma remained concealed, resulting in a carbon-rich aqueous fluid phase.

It should be emphasized that although a significant number of hypabyssal mafic bodies of similar composition mapped throughout the Skiddaw Group outcrop 
to the north of Borrowdale (Fortey et al. 1994), yet none of these is known to have associated graphite deposits, nor have the few intrusions of this type that occur within the BVG outcrop. The reason for the Borrowdale graphite deposit to occur in its location is most probably related to the fact that the associated diorite intrusion is in the immediate hanging wall of the Burtness Comb Fault (Fig. 1). This E- to ENEstriking fault is inferred to lie above a repeatedly re-activated, deep-seated basement structure, and hence was one of the fundamental faults that controlled the accumulation and preservation of the BVG (Millward 2002). The fault may in part also mark the northern margin of the Scafell Caldera, a major piecemeal, hydrovolcanic system within the BVG (Branney \& Kokelaar 1994). This active fault system would have provided the necessary channel ways for the ascent of both magma and fluids (Ortega et al. 2010). Therefore, there is a close relationship between the location of the graphite deposit and zones of structural heterogeneity along its host rock that focused fluid flow (Fig. 3). The Burtness Comb Fault likely acted as a preferential weakened zone for failure caused by fluid pressure increase. Such spatial association of ore deposits with zones of localized complexity along long-lived, largescale structures and the relationship between fluid conduits and low-bulk strain fracture networks are also addressed in the SOC model (Hronsky 2009).

SOC systems are typically characterized by situations where the driving energy flux is added slowly relative to the episodes of energy release from the system. Thus, a final useful prediction of the SOC ore-system concept is that ore formation is likely to be associated with specific favourable periods in the evolution of a terrane and that the formation of a deposit can represent either multiple fluid discharge events that are focused through the same rock volume, or a single major event (Hronsky 2009). The evidence from the graphite deposit at Borrowdale is that a single episode of large volume fluid-flow occurred and this represents another major factor controlling its formation. The importance of tectonic control on the mineralization is demonstrated by the concentration of graphite within near-vertical pipe-like bodies developed at the intersection of conjugate normal fractures which are also mineralized. These types of structure, especially the breccia pipes, imply an overpressured, fluid-rich regime which favoured the transport of andesitic and dioritic rocks and/or melts upwards, fracturing of wall-rock and eventually resulted in the precipitation of huge amounts of graphite from the fluids involved (Fig. 3). The structural features indicate therefore that the main mineralization event in Borrowdale was catastrophic, that is, it occurred in a geologically very short period of time 
(Ortega et al. 2010). Once again, this episode of sudden energy change from the system is in good agreement with the predictions of "avalanche events" in the SOC model.

The fracturing and brecciation of the wall-rock by the supra-lithostatic pressured fluid results in a sudden (near) adiabatic expansion of the fluid phase and, consequently, in a drop of the fluid temperature due to a drop in the internal energy of the fluid system. This temperature drop $(\Delta T)$ can be calculated from the isochoric heat capacity of the fluid $\left(\mathrm{C}_{\mathrm{V}}\right)$ and the molar volume change of the fluid phase that occurs during the fluid pressure drop as a result of the expansion $(\Delta \mathrm{V}): \Delta T=\mathrm{C}_{\mathrm{V}} \Delta \mathrm{V}$. The isochoric heat capacity $C_{V}$ can be calculated from its thermodynamic relation with the isobaric heat capacity $\left(C_{P}\right)$ : $C_{P}-C_{V}=\alpha T V / \kappa$, where $\alpha$ and $\kappa$ denote the expansion coefficient and the isothermal compressibility, respectively. For the calculation of the temperature drop, it is assumed that the fluid pressure decreases from lithostatic to hydrostatic, which can be calculated using the relation $P_{\text {hydrostatic }}=$ $\rho_{\text {fluid }} / \rho_{\text {rock }} P_{\text {lithostatic }}$ (Sibson 1996), i.e. in this case the fluid pressure will drop from 2 to $1 \mathrm{kbar}$ using a value of 0.5 for $\rho_{\text {fluid }} / \rho_{\text {rock. }}$. Using thermodynamic data by Shi \& Saxena (1992), this temperature decrease is estimated to be $\sim 100^{\circ} \mathrm{C}$. This instantaneous cooling effect will be counteracted by exothermic hydration reactions, i.e. the formation of chlorite (e.g. Haack \& Zimmermann 1996). An additional effect of chlorite formation is the associated overall reduction in volume, resulting in increased permeability of the rock (Haack \& Zimmermann 1996).

The increase in rock permeability, combined with the fluid pressure drop will increase the fluid flow to the sites of low fluid pressure. The fast fluid decompression (throttling) associated with the flow from a high-pressure to a low-pressure site may occur thermodynamically under near adiabatic-isenthalpic conditions (Wood \& Spera, 1984). Alternatively, this may also occur at a slower pace under near adiabaticisentropic conditions (Wood \& Spera 1984).

In the first scenario above, the fluid can either heat or cool, depending on the Joule-Thompson coefficient of the fluid system. The Joule-Thompson coefficient $\left(\mu_{\mathrm{JT}}\right.$ $=\partial \mathrm{T} / \partial \mathrm{P}$ at constant enthalpy) can be calculated from the relation $\mu_{\mathrm{JT}}=\mathrm{V}(\mathrm{T} \alpha-1) / \mathrm{C}_{\mathrm{P}}$ (Wood \& Spera 1984). It must be noted that a vertical fluid flow will decrease the temperature change caused by the Joule-Thompson effect due to the effect of gravitation (e.g., Ramberg, 1971). The calculations demonstrate that a flow of pure $\mathrm{H}_{2} \mathrm{O}$ from 2 to 1 kbar will result in fluid temperature drop of $\sim 10^{\circ} \mathrm{C}$, whereas a pure 
$\mathrm{CO}_{2}$ fluid will heat up with $\sim 50^{\circ} \mathrm{C}$. These temperature changes become less as $\left|\mu_{\mathrm{JT}}\right|$ decreases as the fluid heats or cools, i.e. they are maximum estimates. $\mathrm{The}^{\mathrm{H}} \mathrm{H}_{2} \mathrm{O}$-rich nature of the Borrowdale fluid system implies that the cooling effect of the fluid was probably not more that $\sim 10^{\circ} \mathrm{C}$.

In the second scenario (slow fluid flow), the fluid will always cool during decompression. This cooling effect, $(\partial \mathrm{T} / \partial \mathrm{P})_{\mathrm{S}}$, can be calculated using the relation $(\partial \mathrm{T} / \partial \mathrm{P})_{\mathrm{S}}=\alpha \mathrm{TV} / \mathrm{C}_{\mathrm{P}}$. For both $\mathrm{CO}_{2}$ and $\mathrm{H}_{2} \mathrm{O}$, adiabatic-isentropic fluid flow will result in cooling of the fluid by $\sim 70^{\circ} \mathrm{C}$.

The thermodynamic effects that took place, i.e. wall rock fracturing, chlorite formation, and fluid flow from high- to low-pressure sites explain the fluid cooling from $\sim 500^{\circ}$ to $\sim 400^{\circ} \mathrm{C}$. At this point it is important to note that graphite deposition from carbon-bearing aqueous fluids is sensitive to $\mathrm{P}, \mathrm{T}, \mathrm{fO}_{2}$, and fluid composition. Both the fluid pressure and temperature decrease cause the opposite effect on the precipitation potential of graphite, since the stability field of graphite + fluid is enlarged with decreasing temperature whereas it will be reduced with increasing pressure (Luque et al. 1998; Luque \& Rodas 1999; Pasteris 1999).

Figure 4 shows the iso-carbon lines (in mol\%) for a $\mathrm{H}_{2} \mathrm{O}-\mathrm{CO}_{2}-\mathrm{CH}_{4}$ dominated fluid system in which the fluid $\mathrm{fO}_{2}$ is buffered by FMQ (Fig. 4a), FMQ-0.3 (Fig. 4b), and $F M Q+0.3$ (Fig. 4c) in PT space. The arrows in Figure 4 indicate a PT change from 2 kbar and $500{ }^{\circ} \mathrm{C}$ (the conditions calculated for the beginning of graphite precipitation; Luque et al. 2009) to $1 \mathrm{kbar}$ and $400^{\circ} \mathrm{C}$ (the temperature estimated for the main stage of graphite deposition; Ortega et al. 2010). It is important to note that the carbon content variation for the given PT change depends on the oxygen fugacity. For a fluid-rock system buffered by $F M Q$, the carbon content of the fluid hardly changes (Fig. 4a). In other words, any carbon precipitation that takes place under these circumstances cannot be explained by a PT change, and only water removal (i.e. changes in the fluid composition) due to hydration reactions can cause carbon supersaturation of the fluid phase. The same is true for a reduced redox state (relative to FMQ) (Fig. 4b). Here, the PT change may actually result in graphite consumption and carbon supersaturation can only occur, again, if $\mathrm{H}_{2} \mathrm{O}$ is removed from the fluid. However, for an oxidised (relative to FMQ) fluid-rock system the PT change will result in carbon supersaturation and $\mathrm{H}_{2} \mathrm{O}$ removal is thus not required (Fig. 4c). In the case of the Borrowdale deposit, massive graphite precipitation was most probably related to the initially high carbon content in the fluids, and also to the hydration reactions during the coeval propylitic alteration that accompanied graphite 
deposition. Such $\mathrm{H}_{2} \mathrm{O}$-consuming reactions would have driven and maintained the fluid composition into the stability field of graphite. Carbon supersaturation was a crucial factor to bring the system into disequilibrium, which was the driving force for massive graphite precipitation through irreversible mass transfer reactions (Fig. 3; Ortega et al. 2010). Both the disequilibrium and the irreversible processes define a complex system (Prigogine \& Nicolis 1977). The carbon supersaturation is evidenced by textural features at different scales, i.e. graphite spherulites at the microscale (Barrenechea et al. 2009) and graphite nodules at the mesoscale (Fig. 3). Nodular textures and spherulitic morphologies resulting from disequilibrium have been reported from other mineral systems (e.g. Archean volcanic rocks; Fowler et al. 2002). This scale invariance of disequilibrium textures (fractal behaviour) is also a common feature of complex systems. Similarly, the formation of chlorite and smectite after olivine in the sub-volcanic host rocks to the Huelma deposit has been reported (Barrenechea et al. 1997; Luque et al. 2009b), thus pointing to the important role played by hydration reactions in the massive precipitation of graphite in such environments.

\section{Conclusions}

Volcanic-hosted graphite deposits are unusual, because volcanic environments are unfavourable for volumetrically large graphite occurrences due to the low carbon contents of magmas and common degassing processes during and after magma emplacement.

Several geological factors must concur for these deposits to be formed, so it can be considered as an example of a self-organized critical system. The key factors influencing graphite mineralization in volcanic settings, as inferred from the detailed study of the Borrowdale deposit, are 1) the unusually high carbon content of the magma, resulting from the assimilation of carbonaceous metasedimentary rocks (Skiddaw Group metapelites in the Borrowdale deposit), 2) the absence of significant degassing, related to the presence of sub-volcanic or hypabyssal intrusions, acting as barriers to flow, 3) the exsolution of a carbon-rich aqueous fluid phase, 4) the presence of structural heterogeneities (Burtness Comb Fault) as suitable weakened zones for rupturing the barrier to fluid flow, 5) the structural control of the deposits, implying an overpressured, fluid-rich regime which favoured focused fluid discharge, and 6 ) temperature changes associated with fluid flow and hydration reactions that 
led to carbon supersaturation of the fluid phase which brought the system into disequilibrium. The combination of all these factors eventually resulted in the precipitation of huge amounts of graphite from the fluid phase through irreversible mass transfer reactions. Therefore, the system behaved as a self-organized critical system.

It must be emphasized that graphite from the two known volcanic-hosted deposits is as highly crystalline as the highest quality graphite currently mined in vein-type deposits associated with granulite terranes (e.g. Sri Lanka or India; Luque et al. 1998). Therefore, volcanic-hosted deposits constitute potential sources of graphite for new technological applications which demand high-quality graphite. Their exploration should take into account the above mentioned key factors.

\section{Acknowledgements}

We thank N. Sleep for his thorough review of the manuscript which helped to improved it. Professor $\mathrm{H}$. Wada is also thanked for his constructive comments on an earlier draft of this paper. We acknowledge the helpful suggestions made by $\mathrm{Dr} \mathrm{C}$. Viedma about SOC systems. This is a contribution from project CGL2010-16008 (MICINN). David Millward publishes with the permission of the Executive Director, British Geological Survey (N.E.R.C.).

\section{References}

BAK, P. 1996. How Nature Works: The science of self-organised criticality. New York: Copernicus Press.

BAK, P., TANG, C. \& Weisenfeld, K. 1987. Self-organized criticality: an explanation of 1/f noise. Physical Reviews Letters, A38, 364-374.

BarRenechea, J.F., Luque, F.J., Rodas, M. \& Pasteris J.D. 1997. Vein-type graphite mineralization in Jurassic volcanic rocks of the External Zone of the Betic Cordillera (southern Spain). Canadian Mineralogist, 35, 1379-1390.

Barrenechea, J.F., luque F.J., Millward, D., Ortega, L., Beyssac, O. \& Rodas, M. 2009. Graphite morphologies from the Borrowdale deposit (NW England, UK): Raman and SIMS data. Contributions to Mineralogy and Petrology, 158, $37-51$. 
Bebout, G.E., Cooper, D.C., Bradley, A.D. \& Sadofsky, S.J. 1999. Nitrogenisotope record of fluid-rock interactions in the Skiddaw aureole and granite, English Lake District. American Mineralogist, 84, 1495-1505.

Beddoe-Stephens, B. \& MASON, I. 1991. The volcanogenetic significance of garnetbearing minor intrusions within the Borrowdale Volcanic Group, Eskdale area, Cumbria. Geological Magazine, 128, 505-516.

Beddoe-Stephens, B., Petterson, M.G., Millward, D. \& Marriner, G.F. 1995. Geochemical variation and magmatic cyclicity within an Ordovician continental-arc volcanic field: the lower Borrowdale Volcanic Group, English Lake District. Journal of Volcanology and Geothermal Research, 65, 81-110.

BRANNEY, M.J. \& KOKELAAR, B.P. 1994. Volcanotectonic faulting, soft-state deformation and rheomorphism of tuffs during development of a piecemeal caldera, English Lake District. Geological Society of America Bulletin, 106, 507-530.

Deines, P., Stachel, T. \& HarRis, J.W. 2009. Systematic regional variations in diamond carbon isotopic composition and inclusion chemistry beneath the Orapa kimberlite cluster, in Botswana. Lithos, 112, suppl. 2, 776-784.

EggleR, D.H., Holloway, J.R. \& Mysen, B.O. 1976. High $\mathrm{CO}_{2}$ solubilities in mantle magmas. Comment. Geology, 4, 198-199.

FERRY, J.M. \& BURT, D.M. 1982. Characterization of metamorphic fluid composition thorough mineral equilibria. In: JM Ferry, editor. Characterization of metamorphism thorough mineral equilibria. Reviews in Mineralogy, 10, 207262.

FITTON, J.G. 1972. The genetic significance of almandine-pyrope phenocrysts in the calc-alkaline Borrowdale Volcanic Group, northern England. Contributions to Mineralogy and Petrology, 36, 231-248.

Fitton, J.G., ThiRlwall, M.F. \& Hughes D.J. 1982. Volcanism in the Caledonian orogenic belt of Britain. In: RS Thorpe, editor. Andesites. New York: Wiley; pp 611-636.

Fortey, N.J., Cooper, A.H., Henney, P.J., Colman, T. \& Nancarrow, P.H.A. 1994. Appinitic intrusions in the English Lake District. Mineralogy and Petrology, 51, 355-375.

Fowler, A.D., Berger, B., Shore, M., Jones, M.I. \& Ropchan J. 2002. Supercooled rocks: development and significance of varioles, spherulites, 
dendrites and spinifex in Archaean volcanic rocks, Abitibi Greenstone belt, Canada. Precambrian Research, 115, 311-328.

Giammanco, S., Gurrieri, S. \& ValenzA, M. 1998. Anomalous soil $\mathrm{CO}_{2}$ degassing in relation to faults and eruptive fissures on Mount Etna (Sicily, Italy). Bulletin of Volcanology, 60, 252-259.

GiggenbaCH, W.F. 1996. Chemical composition of volcanic gases. In: Scarpa R, Tilling RI, editors. Monitoring and mitigation of volcano hazards. Berlin; Springer-Verlag. pp. 221-256.

HAACK, U.K. \& ZIMMERMANN, H.D. 1996. Retrograde mineral reactions: a heat source in the continental crust? Geologische Rundschau, 85, 130-137.

HermanN, J. \& Green, D.H. 2002. Interaction of hydrous granitic melts with carbonates: Implications for devolatilisation in subduction zones. Ninth International Symposium on Experimental Mineralogy, Petrology and Geochemistry Abstracts, 7, 44.

HRONSKY, J.M.A. 2009. Self-organized systems and ore formation: the key to spatially-predictive targeting? In: Williams PJ et al., editors. Smart Science for Exploration and Mining. James Cook University, vol. 1, pp. 19-21.

HuIZENGA, J-M. 2011. Thermodynamic modelling of a cooling C-O-H fluid-graphite system: implications for hydrothermal graphite precipitation. Mineralium Deposita, 46, 23-33.

JendrzejeWski, N., Trull, T.W., Pineau, F. \& Javoy, M. 1997. Carbon solubility in Mid-Ocean Ridge basaltic melt at low pressures (250-1950 bar). Chemical Geology, 138, 81-92.

KANARIS-SOTIRIOU, R. 1997. Graphite-bearing peraluminous dacites from the Erlend volcanic complex, Faeroe-Shetland Basin, North Atlantic. Mineralogical Magazine, 61, 175-184.

Korsakov, A.V. \& HeRmanN, J. 2006. Silicate and carbonate melt inclusions associated with diamonds in deeply subducted carbonate rocks. Earth and Planetary Science Letters, 241, 104-118.

Korsakov, A.V., Theunissen, K. \& SmiRnova, L.V. 2004. Intergranular diamonds derived from partial melting of crustal rocks at ultrahigh-pressure metamorphic conditions. Terra Nova, 16, 146-151.

Korsakov, A.V., Perraki, M., Zedgenizov, D.A., Bindi L., Vandenabeele, P., SUZUKI, A. \& KAGI, H. 2010. Diamond-graphite relationships in ultrahigh- 
pressure metamorphic rocks from the Kokchetav Massif, northern Kazakhstan. Journal of Petrology, 51, 763-783.

LEE, M.K. 1986. A new gravity survey of the Lake District and three-dimensional model of the granite batholith. Journal of the Geological Society, London, 143, 425-435.

LENTZ, D.R. 1999. Carbonatite genesis: a reexamination of the role of intrusionrelated pneumatolytic skarn processes in limestone melting. Geology, 27, 335338.

LıOU, J.G. 1993. Stabilities of natural epidotes. In: Hock V, Koller F, editors. Proceedings of the 125 Jahre Kappenwand Symposium, 7-16.

LOWENSTERN, J.R. 2001. Carbon dioxide in magmas and implications for hydrothermal systems. Mineralium Deposita, 36, 490-502.

Luque, F.J., PAsteris, J.D., Wopenka, B., Rodas, M. \& BARRenecheA, J.F. 1998. Natural fluid-deposited graphite: mineralogical characteristics and mechanisms of formation. American Journal of Science, 298, 471-498.

LUQUE, F.J. \& RODAS, M. 1999. Constraints on graphite crystallinity in some Spanish fluid-deposited occurrences from different geologic settings. Mineralium Deposita, 34, 215-219.

luque, F.J, Ortega, L., Barrenechea, J.F., Millward, D., Beyssac, O. \& HuIZENGA, J-M. 2009a. Deposition of highly crystalline graphite from moderate-temperature fluids. Geology, 37, 275-278.

Luque, J., Barrenechea, J.F., Ortega, L., Rodas, M. \& Millward D. 2009b. Contrasting mineralizing processes in volcanic-hosted graphite deposits. In: Williams PJ et al., editors. Smart Science for Exploration and Mining. James Cook University, vol. 2, 988-990.

MATTEY, D.P. 1991. Carbon dioxide solubility and carbon isotope fractionation in basaltic melt. Geochimica et Cosmochimica Acta, 55, 467-473.

McConnell, B.J., Menuge, J.F. \& Hertogen, J. 2002. Andesite petrogenesis in the Ordovician Borrowdale Volcanic Group of the English Lake District by fractionation, assimilation and mixing. Journal of the Geological Society, London, 159, 417-424.

MilLWARD, D. 2002. Early Palaeozoic magmatism in the English Lake District. Proceedings of the Yorkshire Geological Society, 54, 65-93.

MISRA, K.C. 2000. Understanding Mineral Deposits. Kluwer Academic Publishers. 
Ortega, L., luque, F.J., Barrenechea, J.F., Rodas, M., Millward, D. \& Beyssac, O. 2009. Assimilation, hydrothermal alteration and graphite mineralization in the Borrowdale deposit (UK). In: Williams PJ et al., editors. Smart Science for Exploration and Mining, vol. 1, 257-259.

Ortega, L., Millward, D., luque, F.J., Barrenechea, J.F., Beyssac, O., Huizenga, J-M., Rodas, M. \& Clarke, S.M. 2010. The graphite deposit at Borrowdale (UK): A catastrophic mineralizing event associated with Ordovician magmatism. Geochimica et Cosmochimica Acta, 74, 2429-2449.

PASTERIS, J.D. 1999. Causes of the uniformly high crystallinity of graphite in large epigenetic deposits. Journal of Metamorphic Geology, 17, 779-787.

Pawley, A.R., Holloway, J.R. \& McMillan, P.F. 1992. The effect of oxygen fugacity on the solubility of carbon-oxygen fluids in basaltic melt. Earth and Planetary Science Letters, 110, 213-225.

Pedersen, A.K. \& LaRsen, L.M. 2006. The llugissoq graphite andesite volcano, Nuussuaq, central West Greenland. Lithos, 92, 1-19.

PRIGogINE, I. 1961. Thermodynamics of irreversible processes. 2nd ed. Interscience. PRIGogINE, I. \& Nicolis, G. 1977. Self-organization in non-equilibrium systems. Wiley.

RAMBERG, H. 1971. Temperature changes associated with adiabatic decompression in geological processes. Nature, 234, 539-540.

RIPLEY, E.M., LI, C. \& SHIN, D. 2002. Paragneiss assimilation in the genesis of magmatic Ni-Cu-Co sulfide mineralization at Voisey's Bay, Labrador: $\delta^{34} S$, $\delta^{13} \mathrm{C}$, and Se/S evidence. Economic Geology, 97, 1307-1318.

SANO, Y. \& MARTY, B. 1995. Origin of carbon in fumarolic gas from island arcs. Chemical Geology, 119, 265-274.

Sano, Y. \& Williams, S.N. 1996. Fluxes of mantle and subducted carbon along convergent plate boundaries. Geophysical Research Letters, 23, 2749-2752.

SARDA, P. \& GUILLOT, B. 2005. Breaking of Henry's law for noble gas and $\mathrm{CO}_{2}$ solubility in silicate melt under pressure. Nature, 436, 95-98.

SIBSON, R.H. 1996. Structural permeability of fluid-driven fault-fracture meshes. Journal of Structural Geology, 18, 1031-1042.

SHI, P. \& SAXENA, S.K. 1992. Thermodynamic modelling of the C-H-O-S fluid system. American Mineralogist, 77, 1038-1049.

Stachel, T., Harris, J.W. \& Muehlenbachs, K. 2009. Sources of carbon in inclusion bearing diamonds. Lithos, 112, suppl. 2, 625-637. 
StRENS, R.G.J. 1965. The graphite deposit of Seathwaite in Borrowdale, Cumberland. Geological Magazine, 102, 393-406.

Symonds, R.B., Rose, W.I., Bluth, G.J.S. \& Gerlach TM. 1994. Volcanic-gas studies: methods and applications. In: Carroll MR, Holloway JR, editors. Volatiles in Magmas. Reviews in Mineralogy, 30, 1-66.

TYLER, I. 1995. Seathwaite Wad and the mines of the Borrowdale valley. Blue Rock Publications.

WALLACE, P.J. 2005. Volatiles in subduction zone magmas: concentrations and fluxes based on melt inclusion and volcanic gas data. Journal of Volcanology and Geothermal Research, 140, 217-240.

Weis, P.L., Friedman, I. \& Gleason, J.P. 1981. The origin of epigenetic graphite: evidence from isotopes. Geochimica et Cosmochimica Acta, 45, 2325-2332.

WOOD, S.A. \& SPERA, F.J. 1984. Adiabatic decompression of aqueous solutions: Applications to hydrothermal fluid migration in the crust. Geology, 12, 707-710.

WYLLIE, P.J. \& HUANG, W.L. 1976. High $\mathrm{CO}_{2}$ solubilities in mantle magmas. Geology, 4, 21- 24.

ZHu, Y. \& OgasaWARA, Y. 2002. Carbon recycled into deep earth: evidence from dolomite dissociation in subduction-zone rocks. Geology, 30, 947-950. 


\section{Captions of figures}

Fig. 1 Location and simplified geological map showing the context of the Borrowdale graphite deposit. Geological data from the British Geological Survey 1:50 000scale geological series sheet 29 , Keswick (1999), with volcanotectonic faults from Branney and Kokelaar (1994). CW - Crummock Water (metasomatic) aureole

Fig. 2 a: View down the "Grand Pipe" excavated along the largest mineralized pipelike body in the Borrowdale graphite deposit. Note the breccia of wall rock and quartz fragments. Photograph by Jeff Wilkinson. b: Chlorite-graphite vein along fault plane in andesite. c: Disseminated graphite patches and flakes in hydrothermally altered andesite

Fig. 3 Diagram illustrating the relationship between rocks, melts, fluids, and processes (in italics) involved in the formation of the Borrowdale graphite deposit. a: Graphite nodules in altered andesite from a breccia-pipe body. b: Photomicrograph (transmitted light, crossed polars) showing a radiating aggregate and crystals of epidote (epd) within a graphite (gph) nodule in hydrothermally altered andesite. Key factors influencing massive graphite deposition in volcanic environments are labelled KF1 to KF6. See text for further explanation

Fig. 4 Pressure-temperature diagram showing the iso-carbon lines for a carbon saturated $\mathrm{COH}$ fluid system (Huizenga, 2011) in which the oxygen fugacity is controlled by FMQ (a), FMQ-0.3 (b), and FMQ+0.3 (c) (in $\log _{10}$ units). The calculations were done following the procedure described in Ortega et al. (2010) 

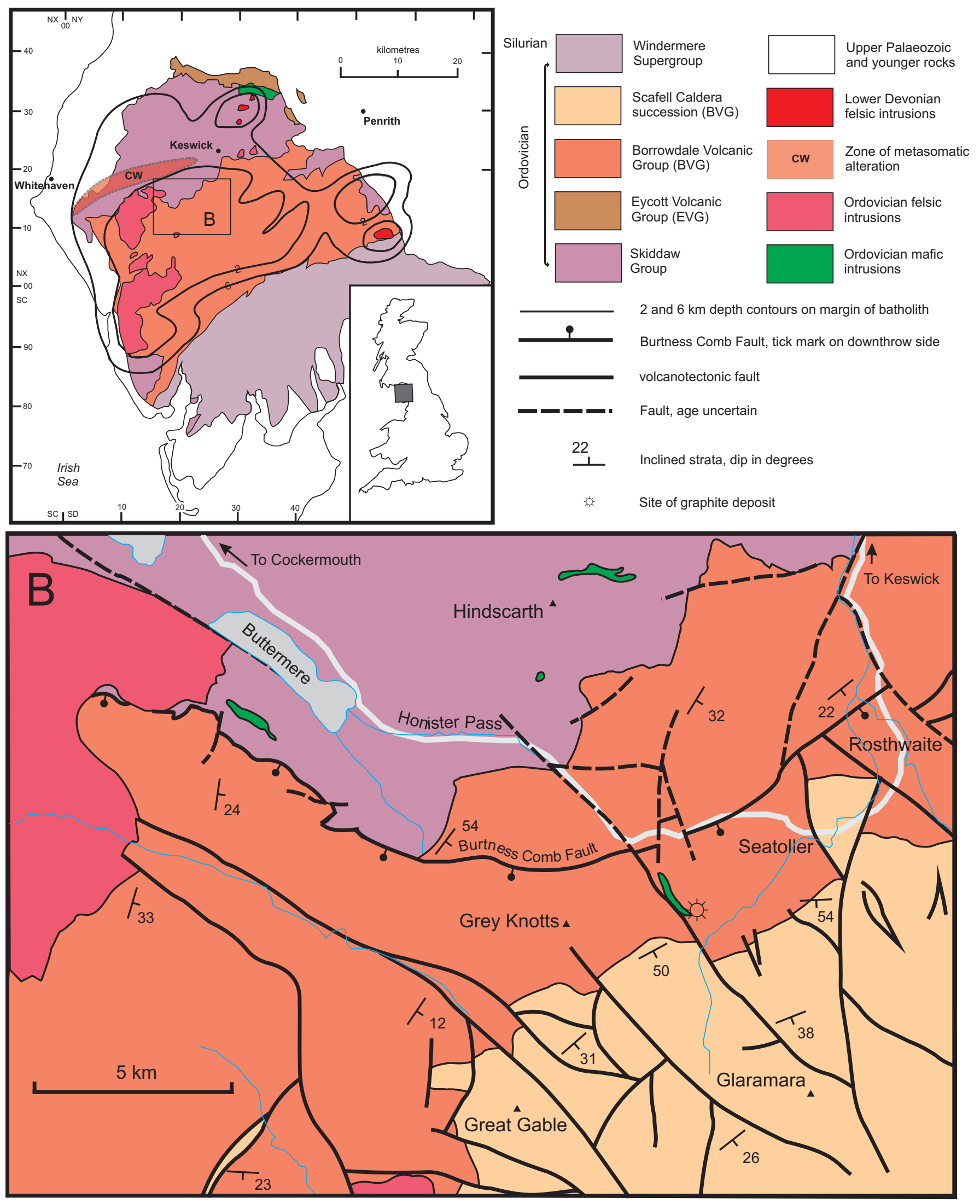

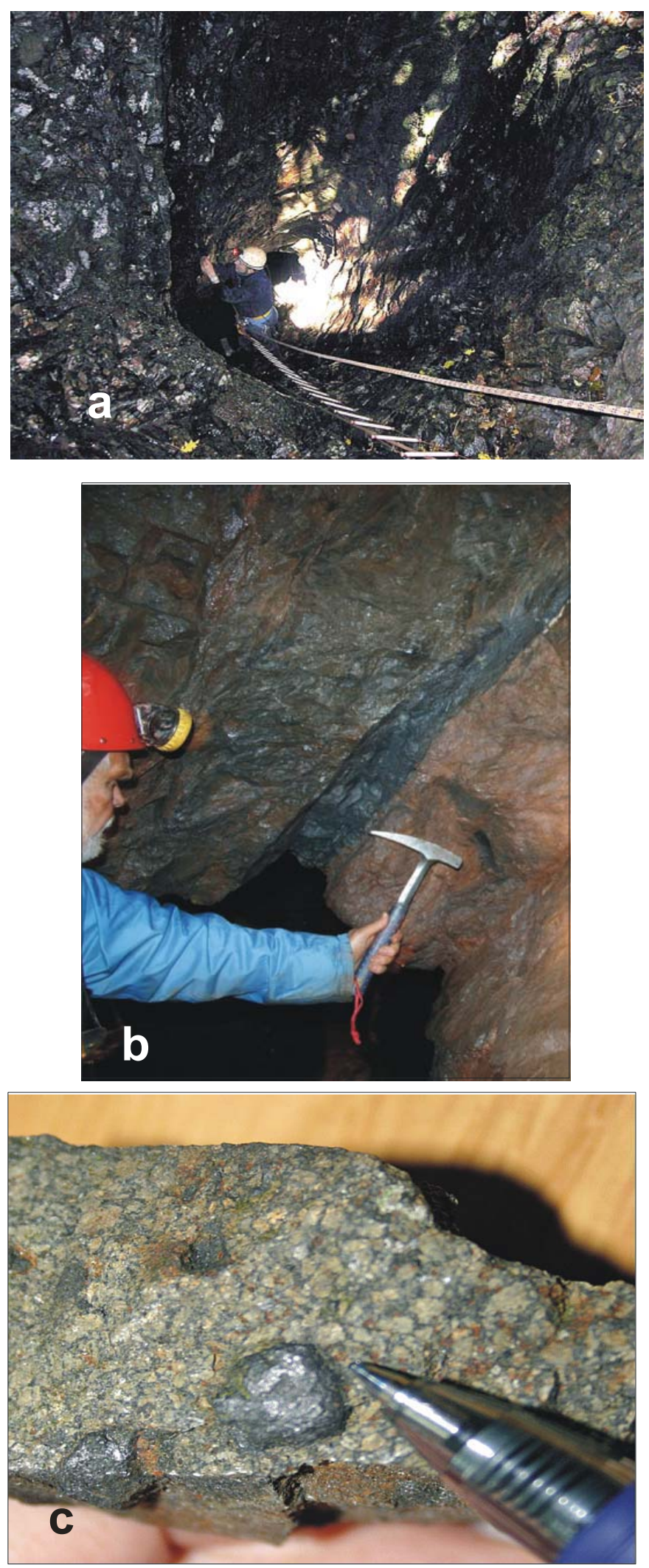

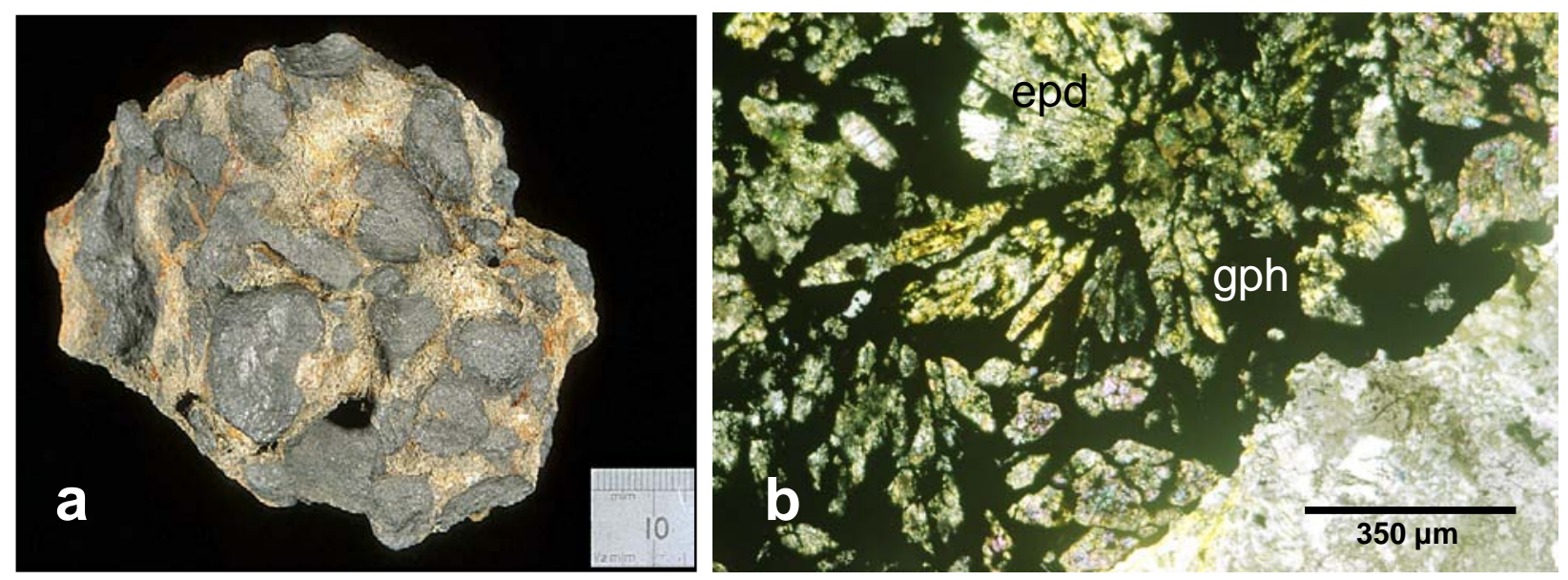

Disequilibrium $\rightarrow$ driving force for graphite precipitation

Graphite mineralization $\longleftrightarrow$ Propylitic alteration

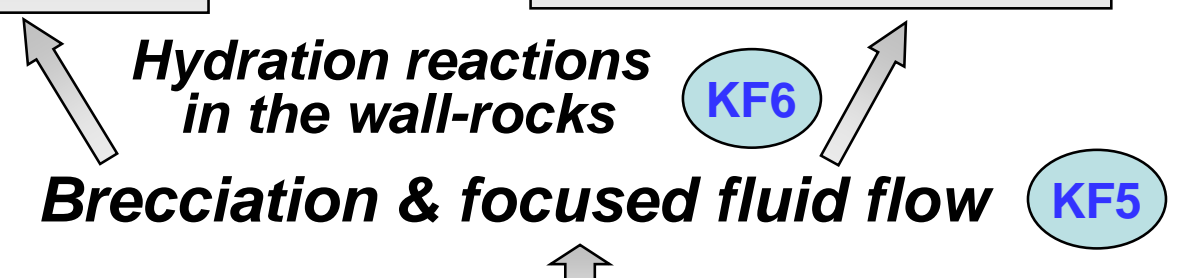

Major crustal fracture system

KF4

No graphite deposits

Subaerial volcanism

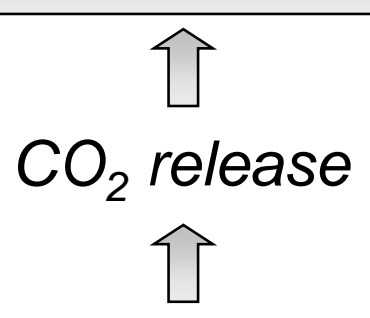

$\mathrm{CO}_{2}$ release

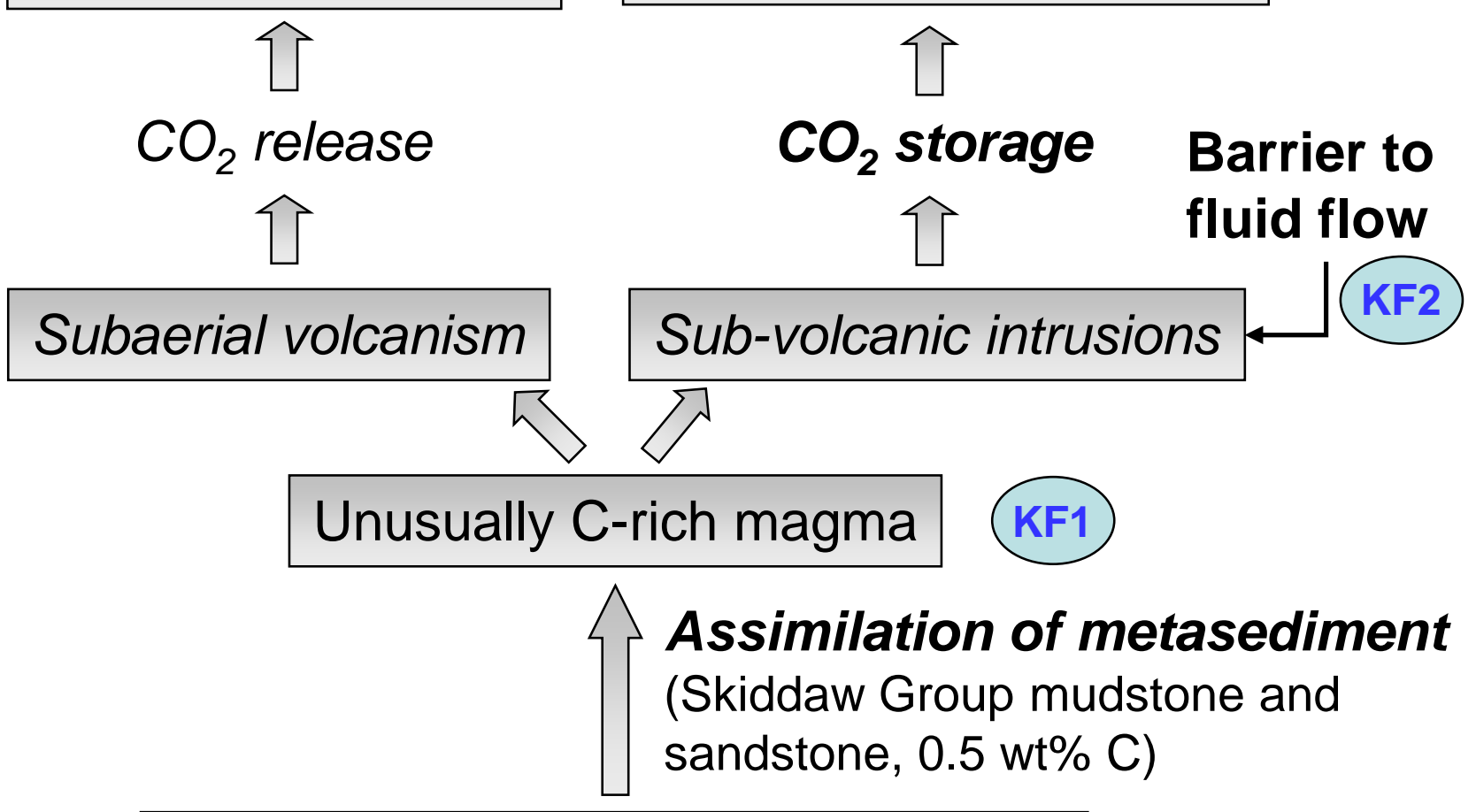

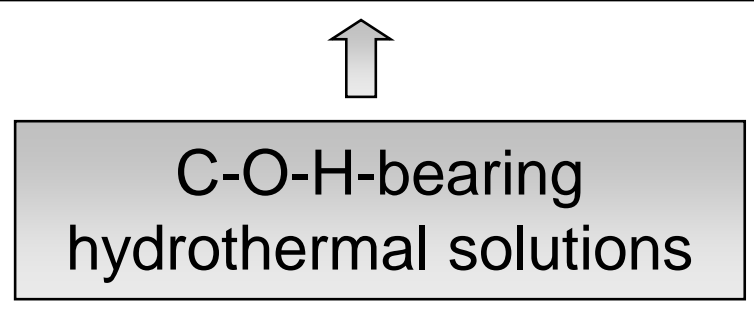

KF3

Hydration reactions in the wall-rocks

$\checkmark$

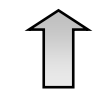

$\mathrm{CO}_{2}$ storage

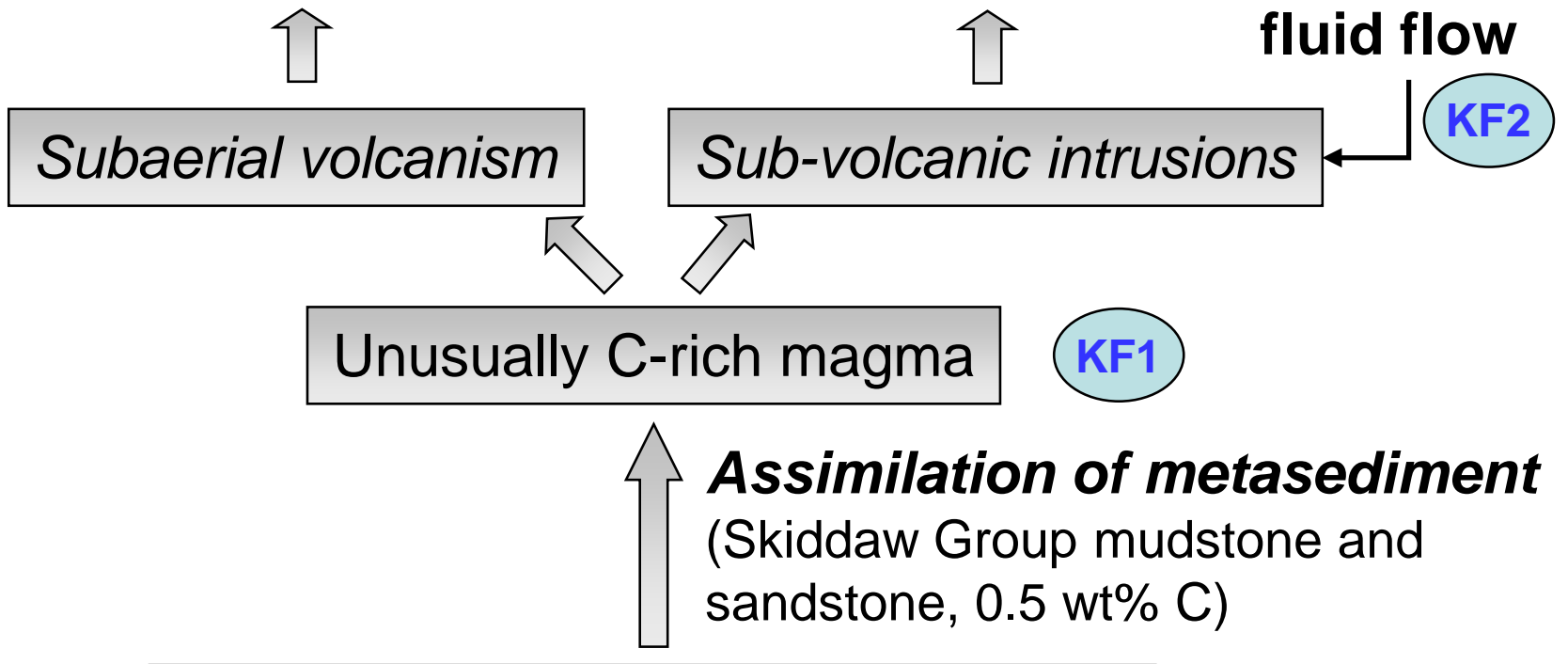

Barrier to fluid flow

Borrowdale Volcanic Group magmas 

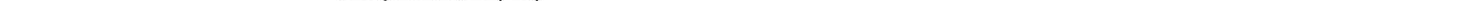


\begin{tabular}{|c|c|c|c|}
\hline Type V & Type VS & Type L1 & Type L2 \\
\hline $\begin{array}{c}\mathrm{VCO}_{2}-\mathrm{CH}_{4}+ \\
\mathrm{LH}_{2} \mathrm{O}\end{array}$ & $\begin{array}{c}\mathrm{VCH}_{4}+\mathrm{LH}_{2} \mathrm{O}+ \\
\mathrm{SC}\end{array}$ & $\begin{array}{c}\mathrm{LH}_{2} \mathrm{O}+\mathrm{VCO}_{2-} \\
\mathrm{CH}_{4}\end{array}$ & $\mathrm{LH}_{2} \mathrm{O}+\mathrm{VCH}_{4}$ \\
\hline $\begin{array}{l}\# \mathrm{XCO}_{2}=0.6-0.8 \\
\mathrm{XH}_{2} \mathrm{O}=0.65\end{array}$ & $\# \mathrm{XCO}_{2}=0$ & $\# \mathrm{XCO}_{2}=0.03-0.6$ & $\# \mathrm{XCO}_{2}=0$ \\
\hline $\begin{array}{c}\mathrm{TH}=295-340^{\circ} \mathrm{C} \\
(\mathrm{V} \text { or } \mathrm{C})\end{array}$ & & $\begin{array}{c}\mathrm{TH}=290-380^{\circ} \mathrm{C} \\
(\mathrm{L})\end{array}$ & $\begin{array}{c}\mathrm{TH}=120-205^{\circ} \mathrm{C} \\
(\mathrm{L})\end{array}$ \\
\hline
\end{tabular}

Table 1. Characteristics of the different types of fluid inclusions recognized in quartz associated with graphite in the Borrowdale deposit. V: Vapor, L: Liquid, C: Critical, SC: Solid carbon (graphite), $\mathrm{X}$ : mole fraction, $\# \mathrm{XCO}_{2}$ : $\mathrm{XCO}_{2} /\left(\mathrm{XCO}_{2}+\mathrm{XCH}_{4}\right)$, TH: Temperature of homogenization. 